\title{
Pengaruh Hormon terhadap Induksi Embrio Somatik Kacapiring (Gardenia jasminoides) dan Potensi Aplikasinya dalam Pembuatan Benih Sintetik
}

\section{Hormones Effect on Somatic Embryo Induction of Kacapiring (Gardenia jasminoides) and Its Potential Application in Synthetic Seeds}

\author{
Yosua Pardede ${ }^{1}$, Exsyupransia Mursyanti ${ }^{1, *}$, Boy Rahardjo Sidharta ${ }^{1}$ \\ 'Prodi Biologi, Fakultas Teknobiologi, Universitas Atma Jaya Yogyakarta \\ Jl. Babarsari No. 44, Depok, Sleman, D.I. Yogyakarta \\ *Email: mursyantiexsyupransia@gmail.com $\quad$ *Penulis Korespondensi
}

\begin{abstract}
Kacapiring (Gardenia jasminoides) is an ornamental plant that has many uses, as a cut flowers, food ingredients, textile materials, cosmetic raw materials, and containing therapeutic compounds. The high demand for gardenia needs to be balanced with the results of its cultivation. Conventional propagation of gardenias has disadvantages such as a long lifecycle, genotypes can differ from the parent, and can carry disease from the parent. Therefore, more efficient gardenia propagation techniques are needed, one of which is by making synthetic seeds. Synthetic seeds can be produced by encapsulating somatic embryos. Somatic embryos are collections of embryonic cells formed from soma cells that have the ability to regenerate into a complete new plant. Hormones are organic materials that occur naturally in plants or are synthetic. Hormones have an effect on plant differentiation and growth. Somatic embryogenesis can be carried out using auxin and cytokinin hormones, because auxins can induce embryogenic callus and cytokinins can initiate the embryogenic process in callus. Synthetic seeds are single somatic embryos covered by a matrix, so that they can be stored for a certain duration of time and can grow into a complete plant in both in vitro and ex vitro conditions. This literature review is to provide an overview based on existing references on the effects of various types of hormones for the induction of gardenia somatic embryos, synthetic seed production methods, and synthetic seed storage temperatures.
\end{abstract}

Keywords: hormone effect, somatic embryo, Gardenia jasminoides, synthetic seeds, encapsulation

\begin{abstract}
Abstrak
Kacapiring (Gardenia jasminoides) merupakan tanaman hias yang memiliki banyak kegunaan, sebagai penghasil bunga potong, bahan makanan, bahan tekstil, bahan baku kosmetik, dan mengandung senyawa terapeutik. Tingginya permintaan kacapiring perlu diseimbangkan dengan hasil budidayanya. Perbanyakan konvensional kacapiring memiliki kelemahan seperti daur hidup yang lama, genotip dapat berbeda dari induk, dan dapat membawa penyakit dari induk. Oleh karena itu, diperlukan teknik perbanyakan kacapiring yang lebih efisien, salah satunya adalah dengan membuat benih sintetik. Benih sintetik dapat dihasilkan dengan cara melakukan enkapsulasi embrio somatik. Embrio somatik adalah kumpulan sel embrionik yang terbentuk dari sel soma yang memiliki kemampuan untuk beregenerasi menjadi tanaman baru yang utuh. Hormon merupakan bahan organik yang terdapat secara alami pada tumbuhan atau sintetik. Hormon berpengaruh dalam diferensiasi dan pertumbuhan tanaman. Embriogenesis somatik dapat dilakukan menggunakan hormon auksin dan sitokinin, karena auksin dapat menginduksi kalus embriogenik dan sitokinin dapat menginisiasi terjadinya proses embriogenik pada kalus. Benih sintetik adalah embrio somatik tunggal yang diselubungi oleh matrik, sehingga dapat disimpan dengan durasi waktu tertentu dan dapat tumbuh menjadi tanaman yang utuh dalam keadaan in vitro maupun exvitro.
\end{abstract}

Kata Kunci: pengaruh hormon, embrio somatik, Gardenia jasminoides, benih sintetik, enkapsulasi 


\section{Pendahuluan}

Tanaman kacapiring (Gardenia jasminoides) adalah tanaman hias yang berasal dari Cina dan banyak tumbuh di daerah dataran sedang (Xiao et al., 2017). Kacapiring memiliki banyak manfaat, yaitu sebagai penghasil bunga potong, bahan makanan, bahan tekstil, bahan baku kosmetik, dan mengandung senyawa terapeutik (Uswatunnisa et al., 2018). Aktivitas terapeutik kacapiring sebagai antidiabetes, antioksidan, anti inflamasi, dan meningkatkan kualitas tidur. Hal ini disebabkan karena kandungan senyawa seperti iridoid, iridoid glukosida, triterpenoid, asam organik, dan senyawa volatil (Xiao et al., 2017).

Menurut Kobayashi dan Kaufman (2006), Gardenia merupakan tanaman perdu dengan tinggi berkisar $0,5-2,5$ meter. Daunnya tebal, berwarna hijau, berbentuk oval, posisi daun berhadapan, dan dilapisi lilin. Bunganya berwarna putih dan harum, bunga dapat muncul satu atau dua buah tergantung dari varietasnya. Menurut ITIS (2011), tanaman kacapiring termasuk dalam kelas Magnoliopsida, bangsa Gentianales, suku Rubiaceae, marga Gardenia, dan nama binominal Gardenia jasminoides.

Perbanyakan tanaman kacapiring dapat dilakukan secara generatif maupun vegetatif. Perbanyakan secara generatif menggunakan biji. Oleh karena tanaman ini berbunga pada umur $2-3$ tahun, maka perbanyakan menggunakan biji perlu menunggu sampai tanaman dewasa (Kobayashi dan Kaufmans, 2006). Kekurangan dari perbanyakan dengan biji adalah tanaman yang dihasilkan belum tentu memiliki sifat unggul seperti induk, kualitas tanaman baru dapat terlihat ketika tanaman sudah berbuah, dan dapat mewarisi penyakit dari induk (Rahardja dan Wiryanta, 2003).

Perbanyakan vegetatif dapat dilakukan secara stek yang dapat dilakukan hampir setiap tahun. Proses stek dilakukan dengan memotong tunas terminal yang berumur $6-8$ minggu dengan ukuran 4-6 inci. Dengan cara ini, kacapiring dapat tumbuh kurang dari satu tahun (Kobayashi dan Kaufman, 2006). Kelemahan dari perbanyakan ini adalah sistem perakaran tanaman lemah, jumlah perbanyakan dari satu induk terbatas, dan waktu yang dibutuhkan untuk mendapatkan tanaman baru relatif lama (Rahardja dan Wiryanta, 2003).

Siklus hidup dari kacapiring yang lama menjadi kendala untuk budidayanya. Oleh karena itu diperlukan metode perbanyakan yang dapat memberikan hasil yang banyak dalam waktu singkat, dan memiliki genotip yang baik seperti induknya. Cara yang dapat dilakukan adalah menggunakan teknologi benih sintetik (Prakash et al., 2018). Benih sintetik dapat digunakan untuk menghasilkan tanaman yang identik dengan induknya dan dapat dipindahkan langsung ke tanah (Guan et al., 2016).

Pembentukan benih sintetik diawali dengan tahap persiapan propagul yang akan digunakan, salah satunya menggunakan embrio somatik (Rihan et al., 2017). Untuk menghasilkan embrio somatik dapat dilakukan dengan cara menginduksi eksplan menggunakan hormon untuk menghasilkan kalus yang bersifat embriogenik, yang mempunyai ciri berwarna putih bening atau putih kekuningan dan memiki tekstur meremah (Indrianto dan Rusdianto, 2012).

Embriogenesis somatik tidak langsung dapat diinduksi menggunakan hormon TDZ, IAA, IBA, NAA, dan 2,4-D baik secara tunggal atau dengan kombinasi (Gabr et al., 2017; Farzinebrahimi et al., 2014; Gaber dan Barakat, 2019; Reddy dan Saritha, 2012). TDZ adalah turunan senyawa urea yang tidak memiliki cincin purin yang biasanya terdapat pada hormon sitokinin seperti benzil amino purin, kinetin, atau zeatin (Lu, 1993). Hormon IAA, IBA, NAA, dan 2,4-D termasuk dalam golongan auksin (Farzinebrahimi et al., 2014).

Pembuatan benih sintetik dilakukan dengan mencelupkan propagul ke dalam larutan alginat, kemudian dicelupan kembali pada larutan kalsium klorida, selanjutnya benih sintetik yang terbentuk dibersihkan menggunakan akuades steril (Faisal dan Alatar, 2019). Propagul berupa embrio somatik pada fase torpedo atau kotiledon sering digunakan untuk produksi benih sintetik, karena pada fase ini embrio mengalami perubahan dari heterotropik menjadi autotropik yang memungkinkan embrio tumbuh secara mandiri untuk menjadi tanaman yang utuh (Jha dan Ghosh, 2005).

Pada awalnya teknologi benih sintetik hanya mencakup enkapsulasi embrio somatik, namun seiring perkembangannya dapat dibuat 
dari bagian tanaman lain seperti tunas apikal (Hatzilazarou et al., 2019), tunas lateral (Varis et al., 2018), nodus (Hatzilazarou et al., 2019), dan tunas mikro (Kamińska et al., 2018; Prihatini dan Hadiati, 2019). Benih sintetik bukan hanya dapat berguna sebagai metode perbanyakaan yang cepat dengan hasil yang baik, tetapi salah satu cara untuk perbanyakaan dari tanaman dengan benih yang rekalsitran (Sharma dan Manchanda, 2019), tingkat perkecambahan rendah (Jainol dan Gansau, 2017), dan konservasi genetik (Kamińska et al., 2018). Benih sintetik dapat dibuat menggunakan natrium alginat yang ditambah dengan larutan polimerisasi seperti kalsium klorida (Ghanbarali et al., 2016) atau kalsium nitrat (Haque dan Ghosh, 2016).

\section{Embriogenesis somatik}

Kultur in vitro adalah teknik menumbuhkan bagian dari tanaman seperti sel, jaringan, atau organ secara steril pada medium buatan. Medium yang digunakan dapat ditambahkan nutrisi dan hormon untuk menginduksi regenerasi sel. Kultur in vitro didasari oleh kemampuan totipotensi sel, sehingga sel yang ditanam pada medium yang mengandung nutrisi dan hormon dapat tumbuh menjadi tanaman yang utuh dan memiliki sifat yang mirip dengan induknya (Anitasari et al., 2018). Dengan metode kultur in vitro, eksplan yang merupakan bagian tanaman dapat diinduksi untuk menghasilkan embrio somatik. Embrio somatik adalah kumpulan sel embrionik yang terbentuk dari sel soma yang memiliki kemampuan untuk beregenerasi menjadi tanaman baru yang utuh (Taryono, 2016).

Embriogenesis somatik adalah tahapan perkembangan sel somatik tumbuhan untuk melakukan dediferensiasi menjadi sel embrionik yang totipoten yang mampu berkembang menjadi tanaman utuh pada kondisi yang tepat (Guan et al., 2016). Embriogenesis somatik akan membentuk sel menjadi struktur bipolar yang memiliki meristem tunas dan meristem akar (Mastuti, 2017). Menurut Slater et al. (2003), embriogenesis somatik dapat dilakukan secara langsung maupun tidak langsung. Embriogenesis somatik secara tidak langsung melibatkan dediferensiasi dari jaringan yang teratur menjadi kalus terlebih dahulu untuk membentuk embrio somatik, sedangkan pembentukan embrio somatik dari dediferensiasi dari jaringan yang teratur tanpa didahului pembentukan kalus disebut dengan proses embriogenesis somatik langsung. Menurut Taryono (2016), terdapat 4 tahapan dalam embriogenesis somatik, yaitu:

1. Induksi kalus embriogenik

Induksi kalus embriogenik ditentukan banyak faktor seperti eksplan, medium, hormon, dan lingkungan. Untuk dapat melakukan induksi kalus embriogenik dapat digunakan hormon auksin, dan jenis yang sering digunakan adalah 2,4-D. Penggunaan sitokinin atau kombinasi dengan auksin juga dapat menginduksi kalus embriogenik pada beberapa jenis tanaman.

2. Perbanyakan kalus embriogenik

Kalus embriogenik yang telah terbentuk dapat diperbanyak di dalam medium cair ataupun padat. Perbanyakan kalus embriogenik dalam medium cair lebih baik, karena distribusi nutrisi dan hormon menyeluruh. Penggunaan medium cair perlu diberikan perlakuan penggojokan agar dapat memberikan oksigen ke kalus embriogenik.

3. Maturasi embrio somatik

Faktor yang mempengaruhi maturasi dari embrio somatik adalah asam absisat. Asam absisat mampu menunda perkecambahan dini dan mengendalikan pemasakan embrio somatik.

4. Perkecambahan embrio somatik

Faktor yang penting pada perkecambahan embrio somatik adalah menjaga kandungan air dan kelembaban pada medium maturasi, sehingga benih masih dapat dikecambahkan meskipun telah satu tahun. Untuk perkecambahan diperlukan sumber energi berupa gula sebanyak $20-30 \mathrm{~g} / \mathrm{l}$.

Menurut Ibrahim et al. (2015), embriogenesis somatik dapat dibagi berdasarkan cara terbentuknya embrio somatik, yaitu embriogenesis somatik primer dan embriogenesis somatik sekunder. Embrio somatik primer merupakan embrio somatik yang terbentuk dari eksplan awal baik pada embriogenesis langsung atau tidak langsung, sedangkan embrio somatik sekunder merupakan embrio somatik yang berasal dari proliferasi embrio somatik primer (Ibrahim et al., 2018). Embrio somatik sekunder dapat dimanfaatkan untuk perbanyakan tanaman klonal dan pemuliaan tanaman (Buzzy et al., 
2007). Keuntungan lain dari penggunan embrio somatik sekunder adalah dapat digunakan sebagai cadangan eksplan yang steril sehingga langsung dapat digunakan tanpa melakukan tahap sterilisasi, tidak perlu melakukan induksi embrio somatik, dan dapat digunakan untuk target transformasi (Ibrahim et al., 2015).

Menurut Yelnititis (2013), kalus embriogenik memiliki memiliki ciri fisik seperti isodiametrik, berwarna putih kekuningan, perlahan akan berubah menjadi embrio somatik globular dan akan tumbuh menjadi besar dan berwarna hijau. Penelitian
Shimizu et al. (1997) menunjukkan bahwa kalus pada tanaman Iris germanica berwarna kekuningan yang mampu membentuk embrio somatik dan beregenerasi menjadi plantlet. Menurut Yelnititis (2013), kalus embriogenik tanaman Shorea pinanga berwarna kekuningan, nodular, meremah, dan embrio somatik globular dapat berkembang membentuk embrio somatik kotiledon yang berwarna hijau pada medium padat dan berwarna hijau muda pada medium cair.

Berikut adalah perbedaan morfologi dari embrio somatik tanaman dikotil dan monokotil yang disajikan pada Gambar 1.

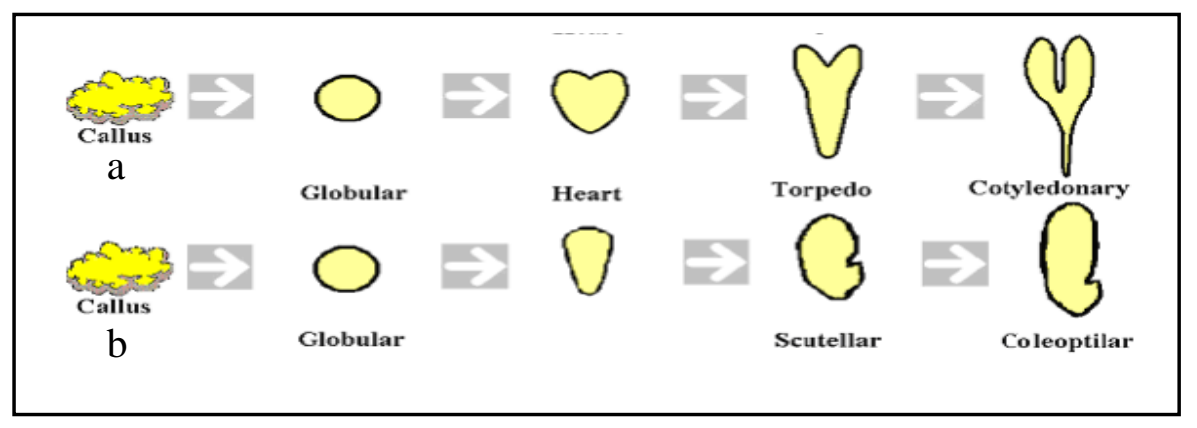

Gambar 1. Perbedaan fase perkembangan embrio somatik (a) dikotil dan (b) monokotil (Sumber: Greer, 2008)

Fase perkembangan embriogenesis pada dikotil (Gambar 1a) diawali dengan terbentuknya embrio globular yang akan mengalami pertumbuhan isodiametrik dan membentuk simetri bilateral. Embrio somatik kemudian akan berbentuk jantung yang nantinya akan berkembang menjadi akar dan meristem tunas. Selanjutnya, embrio somatik berkembang menjadi bentuk torpedo dan fase terakhir akan berbentuk kotiledon yang berwarna hijau. Hipokotil pada plantlet akan memanjang dan terbentuk rambut akar (Zimmerman, 1993). Kacapiring merupakan tanaman kelas Magnoliopsida atau tanaman dikotil, sehingga perkembangan embrionya melalui tahap torpedo dan kotiledon.

Pada embriogenesis monokotil (Gambar 1b) diawali dengan terbentuknya embrio globular yang akan berkembang menjadi bentuk jantung, scuttelar, dan fase akhir coleoptilar (Deo et al., 2010). Pada fase globular akan terjadi perkembangan skutelum, koleoptilar, dan diferensiasi jaringan dengan sistem vaskular embriogenik. Fase akhir perkembangan embrio, koleoptil akan membesar dan sumbu embrio akan membesar. Sumbu embrio akan tumbuh secara lateral dan sejajar dengan skutelum, sedangkan apikal akar akan tumbuh di dalam, sedangkan apikal pucuk akan tumbuh ke luar dan melindungi koleoptil (Gray, 1992).

Perkembangan plantlet dari embrio somatik yang berkecambah merupakan proses pemanjangan hipokotil, perkembangan perakaran, dan pelebaran daun. Tingkat kemampuan perubahan embrio somatik menjadi plantlet bergantung pada genotip, spesies, dan sistem kulturnya (Jaiwal dan Singh, 2003). Pada embrio somatik yang telah dewasa, yaitu embrio fase torpedo atau kotiledon, memiliki struktur bipolar yang memiliki meristem pada ujung terminalnya. Meristem ini berfungi untuk morfogenesis dengan membentuk organ baru, seperti pucuk, daun, dan akar (Bhojwani, 2012).

Penggunaan embrio somatik pada fase torpedo atau kotiledon umum digunakan sebagai propagul untuk pembuatan benih sintetik, karena kemampuannya beregenerasi menjadi plantlet jauh lebih tinggi dibandingkan dengan fase embrio yang lainnya (Gupta dan Ibaraki, 2006). Umumnya embrio somatik yang digunakan berukuran lebih kecil dari 5 mm (Baskaran et al., 2014). 
Terdapat beberapa penelitian yang menggunakan embrio somatik pada tahap torpedo untuk pembentukan benih sintetik, yaitu Haque dan Ghosh (2016) menggunakan tanaman L. revoluta, Raju et al. (2016) menggunakan tanaman $M$. ginger, Micheli dan Standardi (2016) mengunakan tanaman Citrus spp., Sumaryono dan Rizka ( 2015) maupun Muslihatin et al. (2018) menggunakan tanaman C. sinensis, Roostika et al. (2012) menggunakan tanaman A. comosus, dan Himayani dan Muslihatin (2017) menggunakan tanaman M. oleifera. Menurut Yelnititis (2013), embrio somatik tahap globular atau jantung perlu mengalami pendewasaan menjadi embrio somatik tahap kotiledon, sehingga penggunaan embrio somatik yang belum dewasa untuk benih sintetik tidak dianjurkan.

\section{Pengaruh Hormon Terhadap Embriogenesis Somatik}

Menurut Purwanta et al.(2015), hormon berperan penting untuk pertumbuhan dan perkembangan tanaman. Tumbuhan memproduksi hormon untuk mengatur proses fisiologisnya, tanpa adanya hormon tidak akan terjadi pertumbuhan pada tanaman.

Menurut Anggraeni et al. (2012), keberhasilan embriogenesis somatik bergantung dari jenis eksplan, genotipe tanaman induk, kondisi fisiologis. Embriogenesis somatik dapat diinduksi menggunakan hormon auksin dan sitokinin, karena auksin dapat menginduksi kalus embriogenik dan sitokinin dapat menginisiasi terjadinya proses embriogenik pada kalus (George et al., 2008). Embriogenesis pada tanaman dengan marga Gardenia dapat diinduksi menggunakan hormon IAA, IBA, NAA, dan 2,4-D baik secara tunggal maupun dengan kombinasi. Hormon IAA dan IBA merupakan auksin yang terdapat secara alami pada tumbuhan, sedangkan NAA dan 2,4-D merupakan auksin sintetik.

Hormon auksin dapat meningkatkan kemampuan pembelahan sel dan diferensiasi pada saat pembentukan embrio somatik (Aboshama, 2011). Menurut Paunescu (2008), tingginya konsentrasi auksin indigenous dapat menimbulkan pembelahan yang menyimpang pada fase globular. Keberadaan auksin pada medium induksi embrio somatik dibutuhkan pada saat awal embrio somatik akan memasuki fase globular menjadi fase jantung (Ramarosandratana dan Staden, 2004), tetapi keberadaan auksin pada fase globular akhir akan menghambat diferensiasi yang mengakibatkan jaringan kembali ke fase sebelum diferensiasi (Bhojwani, 2012).

Hormon sitokinin berfungsi untuk spesifikasi sel, dediferensiasi, dan diferensiasi (Chen dan Baluska, 2013). Menurut Capuana dan Debergh (1997), pertumbuhan pada embrio somatik disebabkan oleh aktifitas sitokinin pada saat diferensisasi sel-sel kalus. Thidiazuron mampu menstimulasi perbanyakan tanaman berkayu yang bersifat rekalsitran. Pada konsentrasi lebih dari $1 \mu \mathrm{M}$ atau $0,22 \mathrm{ppm}$, TDZ dapat menginduksi kalus, tunas adventif, atau embrio somatik secara efektif (Huetteman dan Preece, 1993). Penggunaan TDZ yang lebih besar atau kurang dari $0,5 \mathrm{mg} / \mathrm{l}$ dapat menyebabkan tidak sinkronnya proses differensiasi embrio somatik (George et al., 2008).

Menurut Capelle et al. (1983), mekanisme kerja dari TDZ adalah melakukan pengubahan sitokinin ribonukleotida menjadi ribonukleotida yang memiliki aktivitas biologi yang lebih tinggi. Menurut Thomas dan Katterman (1986), TDZ memacu pembentukan sitokinin purin indigenous atau menghambat proses degradasi sitokinin. Menurut Verma et al. (2016), TDZ mampu meningkatkan pasokan purin untuk pembelahan sel, dan juga bertindak sebagai pengubah adenin menjadi adenosin yang berfungi untuk menginduksi pembentukan embrio somatik yang selanjutnya dapat digunakan sebagai bahan benih sintetik.

TDZ merupakan hormon yang dapat menginduksi embrio somatik pada tanaman berkayu dengan konsentrasi lebih dari $1 \mu \mathrm{M}$ atau 0,22 ppm, karena memiliki aktivitas yang mirip seperti sitokinin, yaitu melakukan pembelahan sel dan organogenesis (Huetteman dan Preece, 1993). Menurut Lestari (2015), konsentrasi TDZ untuk menginduksi embrio somatik dapat dilakukan menggunakan konsentrasi yang rendah, yaitu sekitar $0,1-0,5$ $\mathrm{mg} / \mathrm{l}$. Terjadinya abnormalitas dan terhambatnya pertumbuhan embrio somatik dapat disebabkan oleh konsentrasi TDZ yang terlalu tinggi, karena TDZ merupakan herbisida yang dapat membunuh jaringan pada eksplan dan menyebabkan penyimpangan pada perkembangan jaringan tanaman (Ouyang et al., 2016). 
Menurut Gray (2005), tahapan terpenting pada embriogenesis somatik adalah terjadinya pendewasaan embrio somatik. Hormon yang digunakan pada medium akan menentukan proses pendewasaan embrio somatik, karena jika hormon yang digunakan tidak sesuai untuk proses pendewasaan maka sel-sel yang sudah mengalami diferensiasi untuk membentuk embrio somatik akan kembali menjadi sel-sel yang tidak terdiferensiasi atau terjadi pembentukan embrio somatik sekunder. Pendewasaan embrio somatik melibatkan proses perubahan akumulasi asam absisat (Preeti et al., 2004) dan fase penurunan kadar air pada embrio somatik untuk mengakumulasi asam absisat (Marquez-Martin et al., 2011). Asam absisat biasanya digunakan untuk proses pendewasaan embrio somatik (Corredoira et al., 2003). Beberapa penelitian mengenai induksi embrio somatik pada marga Gardenia dengan menggunakan variasi hormon dapat dilihat pada Tabel 1.

Berdasarkan Tabel 1 yang telah disajikan, terdapat beberapa penelitian induksi embrio somatik pada tanaman marga Gardenia yang dapat diinduksi menggunakan beberapa jenis hormon seperti TDZ, IAA, IBA, NAA dan 2,4-D. Hormon TDZ termasuk dalam golongan sitokinin yang dapat menginduksi embrio somatik dengan mengubah sitokinin ribonukleotida menjadi ribonukleotida yang memiliki aktivitas biologi yang lebih tinggi (Capelle et al.,1983). Menurut Verma et al. (2016), TDZ mampu meningkatkan pasokan purin untuk pembelahan sel, dan mengubah adenin menjadi adenosin yang berfungi untuk proses pembelahan sel dan sintesis protein yang terjadi pada saat pembentukan embrio somatik.

Menurut George et al. (2008), hormon auksin seperti IAA, IBA, NAA, dan 2,4-D dapat menginduksi terjadi embriogenesis somatik dengan melakukan terminasi pada ekspresi gen awal, dan mengaktifkan gen yang berfungsi untuk menghasilkan sel embriogenik. Proses terminasi gen ini disebut dengan metilasi DNA (Loschiavo et al., 1989). Menurut Nowak et al.(2015), hormon auksin dapat menstimulasi gen LEC2 (LEAFY COTYLEDON 2) yang menjadi kunci dalam tahap awal dan tahap akhir embriogenesis somatik, dengan mengatur interaksi auksin etilen.

Gabr et al. (2017), melakukan induksi embrio somatik tidak langsung menggunakan TDZ $4 \mathrm{mg} / \mathrm{l}$, dan tidak melaporkan adanya abnormalitas pada perkembangan embrio somatik. Namun penelitian yang dilakukan oleh Ouyang et al. (2016), melaporkan bahwa hasil kultur tanaman $M$. ovalifolia yang diinduksi menggunakan TDZ $10 \mu \mathrm{M}$ mengalami penyimpangan pada bentuk bunga pada anter dan petala, dan bentuk tanaman. Sunandar et al. (2017), melaporkan penyimpangan pada pembelahan sel yang asimetri pada fase kotiledon. Embrio somatik yang terbentuk tidak dapat mengalami perkecambahan dan pertumbuhan embrio somatik terhambat.

Induksi embrio somatik yang menggunakan sitokinin saja memang dapat dilakukan, namun sangat langka. Pada banyak spesies konsentrasi rendah dari sitokinin antara $0,1-1 \mu \mathrm{M}$ dapat menginduksi proses embriogenesis (George et al., 2008). Menurut Lestari (2015), konsentrasi TDZ untuk menginduksi embrio somatik dapat dilakukan menggunakan konsentrasi yang rendah, yaitu sekitar $0,1-0,5 \mathrm{mg} / \mathrm{l}$. Terjadinya abnormalitas dan terhambatnya pertumbuhan embrio somatik dapat disebabkan oleh konsentrasi TDZ yang terlalu tinggi, karena TDZ merupakan herbisida yang dapat membunuh jaringan pada eksplan dan menyebabkan penyimpangan pada perkembangan jaringan tanaman (Ouyang et al., 2016).

Farzinebrahimi et al. (2014), melakukan embriogenesis somatik secara tidak langsung menggunakan hormon golongan auksin secara tunggal pada tanaman kacapiring (IAA, IBA, NAA, atau 2,4-D dengan konsentrasi 3 mg/l). Gaber dan Barakat (2019) melakukan embriogenesis somatik secara tidak langsung pada tanaman kacapiring dengan menggunakan 2,4-D $1-4 \mathrm{mg} / \mathrm{l}$. Hasil yang sama juga didapatkan oleh Reddy dan Saritha (2012) yang melakukan embriogenesis somatik secara tidak langsung menggunakan hormon 2,4-D dengan konsentrasi $3 \mathrm{mg} / \mathrm{l}$. Auksin sintetik dapat menginduksi pembentukan embrio somatik dengan cara melakukan asidifikasi pada sitoplasma dan dinding sel (Kutschera, 1994). 
Tabel 1. Penelitian induksi embrio somatik pada marga Gardenia

\begin{tabular}{|c|c|c|c|c|c|c|}
\hline Tanaman & Eksplan & Tipe embriogenesis & $\begin{array}{c}\text { Medium induksi embrio } \\
\text { somatik }\end{array}$ & Ciri fisik kalus & $\begin{array}{c}\text { Tingkat } \\
\text { keberhasilan }\end{array}$ & Referensi \\
\hline $\begin{array}{c}\text { Gardenia } \\
\text { jasminoides }\end{array}$ & Daun & Tidak langsung & MS + TDZ 4 mg/l & Hijau keputihan dan meremah & - & (Gabr et al., 2017) \\
\hline $\begin{array}{c}\text { Gardenia } \\
\text { jasminoides }\end{array}$ & Daun & Tidak langsung & $\begin{array}{c}\mathrm{MS}+\mathrm{IAA}, \mathrm{IBA}, \text { atau NAA } 3 \\
\mathrm{mg} / \mathrm{l}\end{array}$ & Hijau kekuningan dan meremah & $100 \%$ & $\begin{array}{c}\text { (Farzinebrahimi } e t \\
\text { al., 2014) }\end{array}$ \\
\hline $\begin{array}{c}\text { Gardenia } \\
\text { jasminoides }\end{array}$ & Nodus & Tidak langsung & $\mathrm{MS}+2,4-\mathrm{D} 1-4 \mathrm{mg} / \mathrm{l}$ & Hijau keputihan dan meremah & $100 \%$ & $\begin{array}{c}\text { (Gaber dan } \\
\text { Barakat, 2019) }\end{array}$ \\
\hline $\begin{array}{c}\text { Gardenia } \\
\text { latifolia } \\
\end{array}$ & Tunas & Tidak langsung & $\mathrm{MS}+2,4-\mathrm{D} 3 \mathrm{mg} / \mathrm{l}$ & Kuning keputihan dan meremah & $80 \%$ & $\begin{array}{c}\text { (Reddy dan } \\
\text { Saritha, 2012) } \\
\end{array}$ \\
\hline
\end{tabular}


$\begin{array}{rlr}\begin{array}{c}\text { Telah } \\ \text { pendahuluan }\end{array} & \text { dilakukan } & \begin{array}{r}\text { penelitian } \\ \text { menginduksi }\end{array}\end{array}$ embriogenesis somatik tanaman kacapiring secara langsung mengunakan daun kacapiring dan hormon TDZ 0,1 - 0,5 ppm. Berdasarkan hasil penelitian tersebut hormon TDZ $0,1-0,5$ ppm tidak dapat menginduksi embriogenesis somatik secara langsung pada daun kacapiring dalam waktu 7 minggu (data tidak dipublikasi). Menurut Ramarosandratana dan Staden (2004), embriogenesis somatik tidak dapat terjadi saat menggunakan TDZ karena tidak adanya hormon auksin pada medium yang digunakan untuk mengawali pembentukan embrio somatik.

Menurut George et al. (2008), penggunaan hormon sitokinin saja dalam proses embriogenesis somatik sangat jarang terjadi, sehingga kebanyakan jenis tanaman memerlukan kombinasi hormon auksin dan sitoknin dalam proses embriogenesis somatik. Penyebab lain tidak terbentuknya embrio somatik pada eksplan kacapiring adalah konsentrasi TDZ yang digunakan masih belum optimal, karena konsentrasi yang optimal dari TDZ bersifat spesifik terhadap suatu spesies (Dewir et al., 2018). Menurut Vesco dan Gurerra (2001), penggunaan jenis eksplan yang bersifat meristematik akan memberikan persentase keberhasilan pembentukan embrio somatik yang lebih tinggi jika dibandingkan jaringan yang non meristematik.

Bentuk fisik kalus embriogenik memiliki ciri berwarna hijau, kekuningan atau keputihan, dan meremah. Warna hijau pada kalus merupakan embrio somatik yang telah dewasa, dan warna kekuningan atau keputihan merupakan embrio somatik tahap awal (Yelnititis, 2013). Sifat meremah pada kalus embriogenik penting untuk proses induksi embrio somatik (Montoro et al., 2012).

\section{Potensi Aplikasi Embrio Somatik Untuk Pembuatan Benih Sintetik}

Benih sintetik adalah embrio somatik tunggal yang diselubungi oleh matrik sehingga dapat disimpan dalam durasi waktu tertentu dan dapat tumbuh menjadi tanaman yang utuh dalam keadaan in vitro maupun ex vitro (Murashige, 1977).Teknologi benih sintetik merupakan metode yang dapat digunakan untuk membudidayakan spesies tanaman yang tidak dapat menghasilkan biji. Benih sintetik dapat menghasilkan tanaman poliploid dengan sifat unggul, efisien waktu dan biaya. Manfaat lain dari benih sintetik adalah mendapatkan tanaman yang sehat, mempunyai keseragaman genetik yang tinggi, dapat digunakan sebagai plasma nutfah, dan dapat langsung dipindahkan ke tanah (Rihan et al., 2017).

Teknologi benih sintetik menjadi pendekatan yang menjanjikan untuk dapat melakukan konservasi tanaman dan menyediakan bibit tanaman untuk komersial (Standardi dan Micheli, 2013). Menurut Rihan et al. (2017), penggunaan benih sintetik mengalami peningkatan dalam perbanyakan tanaman untuk tujuan domestikasi atau konservasi genetik, yang dimulai setelah ditemukannya cara untuk menghasilkan embrio somatik pada tanaman secara in vitro. Benih sintetik mengalami pengembangan dalam penggunaan propagul yang dienkapsulasi, tidak hanya menggunakan embrio somatik saja, tetapi juga penggunaan bagian vegetatif lain seperti tunas aksilar, tunas apikal, tunas mikro, nodus, kalus embriogenik, Protocorm-Like Bodies(PLBs).

Struktur benih sintetik meniru dari biji zigotik. Benih sintetik terdiri dari propagul yang meniru embrio zigotik, dan matrik (senyawa pengeras dan dapat diperkaya dengan nutrien, hormon, anti penyakit, pengontrol aktivitas biologi, atau pupuk), yang meniru endosperm pada biji zigotik (Cartes et al., 2009). Matrik buatan terbuat dari mineral dan vitamin dari medium Murashige dan Skoog (MS). Senyawa komplek untuk pembentukan matrik dibuat dengan mengimersikan embrio somatik ke dalam natrium alginat, lalu dipindahkan ke dalam larutan kalsium klorida (Cartes et al., 2009)

Terdapat beberapa bahan pengeras yang dapat digunakan untuk enkapsulasi propagul seperti agar, alginat, karagenan, guar gum, dan natrium pektratat (George et al., 2008). Menurut Rihan et al. (2017), natrium alginat merupakan salah satu zat pengental yang dapat digunakan untuk pembuatan benih sintetik karena toksisitas yang rendah, murah, cepat untuk menggumpal, dan dapat terdegradasi secara alami. Menurut Himayani dan Muslihatin (2017), penggunaan natrium alginat dengan konsentrasi $4 \%$ merupakan konsentrasi yang paling baik untuk perkecambahan benih sintetik. Penggunaan natrium alginat dengan konsentrasi yang 
terlalu tinggi akan menghasilkan matrik yang terlalu kompak sehingga menghambat kemampuan embrio somatik untuk berkecambah.

Prinsip utama dari enkapsulasi propagul adalah pembentukan komplek kalsium alginat dari pertukaran ion antara $\mathrm{Na}^{+}$ pada larutan natrium alginat dengan ion $\mathrm{Ca}^{2+}$ pada larutan kalsium klorida. Propagul yang akan dienkapsulasi dicelupkan ke dalam larutan natrium alginat, kemudian dicelupkan ke dalam larutan polimerisasi kalsium klorida. Tingkat kekompakan dan bentuk dari matrik dipengaruhi oleh konsentrasi dari kedua larutan tersebut dan durasi pencelupan pada larutan polimerisasi (Rihan et al., 2017). Menurut Faisal dan Alatar (2019), tahapan pembentukan benih sintetik dapat dilakukan dengan tahapan sebagai berikut:

1. Propagul dicelupkan ke dalam larutan natrium alginat $3 \%$

2. Selanjutnya dicelupkan ke dalam larutan polimerisasi seperti kalsium klorida 100 $\mathrm{mM}$ selama $30-40$ menit hingga terbentuk matrik kalsium alginat

3. Kalsium alginat yang telah terbentuk dibersihkan menggunakan akuades steril sebanyak 3 kali

4. Benih sintetik dikeringkan pada kertas saring steril

5. Benih sintetik disimpan pada suhu $4^{\circ} \mathrm{C}$, $15^{\circ} \mathrm{C}$, atau $24^{\circ} \mathrm{C}$

Menurut Jain dan Gupta (2005), keuntungan dari synthetic seeds antara lain mudah untuk dipindahkan, memiliki viabilitas yang lebih lama, dan didapatkan tanaman yang identik dengan induknya. Kerugian dari synthetic seeds adalah dibutuhkan fasilitas yang memiliki harga yang mahal, membutuhkan kemampuan khusus, dan beresiko memperbanyak tanaman mutan yang tidak teramati (Chawla, 2002). Beberapa penelitian yang melakukan enkapsulasi embrio somatik pada beberapa tanaman kelas Magnoliopsida dapat dilihat pada Tabel 2.

Berdasarkan Tabel 2 yang telah disajikan di atas terdapat beberapa penelitian untuk membuat benih sintetik pada tanaman kelas Magnoliopsida. Beberapa penelitian (Micheli dan Standardi, 2016; Muslihatin et al., 2018; Sumaryono dan Rizka, 2015; Calandry et al., 2017; Himayani dan Muslihatin, 2017; Muslihatin et al., 2017; Dhir et al., 2014; Niranjan dan Sudarshana, 2005; Cartes et al., 2009; Rahmi et al., 2017) membuat benih sintetik dengan mengenkapsulasi embrio somatik pada fase torpedo ataupun kotiledon, namun pada penelitian Muslihatin et al. (2018) membuat benih sintetik dengan mengenkapsulasi embrio somatik yang masih globular dan setelah disimpan selama 30 hari embrio somatik mengalami pendewasaan dan masuk pada fase kotiledon. Penggunaan embrio somatik pada fase torpedo atau kotiledon akan meningkatkan kemampuan benih sintetik untuk berkecambah, karena sudah memiliki meristem akar dan tunas (Bhojwani, 2012).

Berdasarkan beberapa penelitian yang telah disajikan di atas dapat diketahui bahwa pembentukan benih sintetik pada tanaman kelas Magnoliopsida lebih banyak menggunakan natrium alginat dengan konsentrasi 4\% dan larutan polimerisasi kalsium klorida dengan konsentrasi $100 \mathrm{mM}$ dengan durasi pencelupan $15-20$ menit. Menurut Calandry et al. (2017), tingkat kekompakan dari matrik benih sintetik akan mempengaruhi kemampuan embrio somatik untuk berkecambah. Matrik yang terbentuk dari kombinasi natrium alginate $4 \%$ dan kalsium klorida $100 \mathrm{mM}$ dengan durasi pencelupan 15-20 menit akan menghasilkan benih sintetik yang secara umum memiliki bentuk yang bulat, dapat menutupi seluruh permukaan embrio somatik, dan matrik tidak mudah rusak.

Penelitian mengenai benih sintetik pada kacapiring belum pernah dilakukan, namun beberapa penelitian pembentukan benih sintetik pada kelas Magnoliopsida dapat digunakan sebagai acuan dalam pembentukan benih sintetik kacapiring. Hal tersebut disebabkan kacapiring merupakan tanaman kelas Magnoliopsida (dikotil) yang memiliki perkembangan embrio somatik yang sama yaitu globular, jantung, torpedo, dan kotiledon (Greer, 2008). Embrio somatik pada fase torpedo atau kotiledon dapat digunakan dalam pembuatan benih sintetik kacapiring. Selain itu, beberapa penelitian menunjukkan bahwa induksi embrio somatik pada marga Gardenia mudah dilakukan dengan menggunakan variasi hormon dengan menggunakan eksplan daun, tunas maupun nodus kaca piring (Tabel 1). 
Tabel 2. Penelitian pembentukan benih sintetik pada kelas Magnoliopsida

\begin{tabular}{|c|c|c|c|c|c|c|c|}
\hline Tanaman & Propagul & Konsentrasi larutan & Bahan tambahan & $\begin{array}{c}\text { Kemampuan } \\
\text { berkecambah } \\
\text { dengan bahan } \\
\text { tambahan } \\
\end{array}$ & $\begin{array}{c}\text { Suhu } \\
\text { penyimpanan }\end{array}$ & $\begin{array}{c}\text { Durasi } \\
\text { penyimpanan }\end{array}$ & Peneliti \\
\hline Citrus spp. & $\begin{array}{l}\text { Embrio } \\
\text { somatik }\end{array}$ & $\begin{array}{l}\text { Natrium alginat } 2,5 \% \text { dan } \\
\text { kalsium klorida } 1,1 \% \\
\text { selama } 25-30 \text { menit }\end{array}$ & $\begin{array}{c}\mathrm{MS}+\text { malt extract } 0,25 \\
\mathrm{mg} / \mathrm{l}+\text { asam askorbat } 0,25 \\
\mathrm{mg} / \mathrm{l}+\text { asam giberelin } \\
(\mathrm{GA}) 1 \mathrm{mg} / \mathrm{l}+\mathrm{NAA} 0,02 \\
\mathrm{mg} / \mathrm{l}+\text { sukrosa } 68 \mathrm{~g}\end{array}$ & - & - & - & $\begin{array}{c}\text { (Micheli dan } \\
\text { Standardi, 2016) }\end{array}$ \\
\hline $\begin{array}{l}\text { Moringaoleifera } \\
\text { sinensis }\end{array}$ & $\begin{array}{l}\text { Embrio } \\
\text { somatik }\end{array}$ & $\begin{array}{c}\text { Natrium alginat } 4 \% \text { dan } \\
\text { kalsium klorida } 75 \mathrm{mM} \\
\text { selama } 15-20 \text { menit } \\
\end{array}$ & $\begin{array}{c}\mathrm{MS}+\mathrm{NAA} 0,3 \mathrm{mg} / \mathrm{l}+\mathrm{BA} \\
3 \mathrm{mg} / \mathrm{l}\end{array}$ & - & - & - & $\begin{array}{c}\text { (Muslihatin et al., } \\
\text { 2018) }\end{array}$ \\
\hline Camellia sinensis & $\begin{array}{l}\text { Embrio } \\
\text { somatik }\end{array}$ & $\begin{array}{c}\text { Natrium alginat } 2 \% \text { dan } \\
\text { kalsium klorida } 100 \mathrm{mM} \\
\text { selama } 20 \text { menit }\end{array}$ & $\mathrm{WP}+$ sukrosa $20 \mathrm{~g} / \mathrm{l}$ & - & - & - & $\begin{array}{l}\text { (Sumaryono dan } \\
\text { Rizka, 2015) }\end{array}$ \\
\hline Camellia sinensis & $\begin{array}{l}\text { Embrio } \\
\text { somatik }\end{array}$ & $\begin{array}{l}\text { Natrium alginat } 4 \% \text { dan } \\
\text { kalsium klorida } 100 \mathrm{~mm} \\
\text { selama } 15 \text { menit } \\
\end{array}$ & MS + sukrosa $3 \%$ & - & - & - & $\begin{array}{l}\text { (Calandry et al., } \\
\text { 2017) }\end{array}$ \\
\hline Moringa oleifera & $\begin{array}{l}\text { Embrio } \\
\text { somatik }\end{array}$ & $\begin{array}{l}\text { Natrium alginat } 4 \% \text { dan } \\
\text { kalsium klorida } 75 \mathrm{mM} \\
\text { selama } 15 \text { menit } \\
\end{array}$ & $\begin{array}{c}\mathrm{MS}+\mathrm{NAA} 3 \mathrm{mg} / \mathrm{l}+\mathrm{BA} 3 \\
\mathrm{mg} / \mathrm{l}\end{array}$ & - & - & - & $\begin{array}{l}\text { (Himayani dan } \\
\text { Muslihatin, 2017) }\end{array}$ \\
\hline Moringa oleifera & $\begin{array}{l}\text { Embrio } \\
\text { somatik }\end{array}$ & $\begin{array}{l}\text { Natrium alginat } 4 \% \text { dan } \\
\text { kalsium klorida } 75 \mathrm{mM} \\
\text { selama } 20-30 \text { menit }\end{array}$ & $\begin{array}{c}\mathrm{MS}+\mathrm{NAA} 0,3 \mathrm{mg} / \mathrm{l}+\mathrm{BA} \\
0,3 \mathrm{mg} / \mathrm{l}+\text { sukrosa } 3 \%\end{array}$ & $41,67 \%$ & - & - & $\begin{array}{l}\text { (Muslihatin et al., } \\
\text { 2017) }\end{array}$ \\
\hline Anethum graveolens & $\begin{array}{l}\text { Embrio } \\
\text { somatik }\end{array}$ & $\begin{array}{c}\text { Natrium alginat } 3 \% \text { dan } \\
\text { kalsium klorida } 100 \mathrm{mM} \\
\text { selama } 20-30 \text { menit } \\
\end{array}$ & MS & $49,3 \%$ & $4^{\circ} \mathrm{C}$ & 60 hari & (Dhir et al., 2014) \\
\hline
\end{tabular}




\begin{tabular}{|c|c|c|c|c|c|c|c|}
\hline $\begin{array}{l}\text { Lagerstroemia } \\
\text { indica }\end{array}$ & $\begin{array}{l}\text { Embrio } \\
\text { somatik }\end{array}$ & $\begin{array}{c}\text { Natrium alginat } 2 \% \text { dan } \\
\text { kalsium klorida } 90 \mathrm{mM} \\
\text { selama } 30 \text { menit }\end{array}$ & - & $22,5 \%$ & $4^{\circ} \mathrm{C}$ & 10 hari & $\begin{array}{c}\text { (Niranjan dan } \\
\text { Sudarshana, 2005) }\end{array}$ \\
\hline $\begin{array}{c}\text { Nothofagus } \\
\text { alpina }\end{array}$ & $\begin{array}{l}\text { Embrio } \\
\text { somatik }\end{array}$ & $\begin{array}{c}\text { Natrium alginat } 4 \% \text { dan } \\
\text { kalsium klorida } 136 \mathrm{mM} \\
\text { selama } 10 \text { menit }\end{array}$ & $\begin{array}{c}\mathrm{MS}+\mathrm{IAA} 0,5 \mathrm{mg} / \mathrm{l}+ \\
\mathrm{NAA} 0,5 \mathrm{mg} / \mathrm{l}+\mathrm{BA} 2 \\
\mathrm{mg} / \mathrm{l}+\text { sukrosa } 30 \mathrm{~g} / \mathrm{l}\end{array}$ & $83 \%$ & - & - & (Cartes et al., 2009) \\
\hline Piper nigrum & $\begin{array}{l}\text { Embrio } \\
\text { somatik }\end{array}$ & $\begin{array}{c}\text { Natrium alginat } 3 \% \text { dan } \\
\text { kalsium klorida } 100 \mathrm{mM} \\
\text { selama } 40 \text { menit } \\
\end{array}$ & $\mathrm{SH}+$ sukrosa $3 \%$ & $80,9 \%$ & $25^{\circ} \mathrm{C}$ & 45 hari & (Rahmi et al., 2017) \\
\hline
\end{tabular}


Metode pembentukan benih sintetik pada tanaman kelas Magnoliopsida dapat digunakan pada tanaman kacapiring dengan menggunakan natrium alginat $4 \%$ dan kalsium klorida $100 \mathrm{mM}$ selama 15 - 20 menit. Konsentrasi dari larutan pengental dan durasi pencelupan pada larutan polimerisasi merupakan hal yang penting dalam pembentukan benih sintetik (Rihan et al., 2017). Matrik benih sintetik yang terlalu lunak tidak mampu untuk melindungi embrio somatik, sedangkan matrik yang telalu keras dapat menghambat respirasi embrio somatik yang dapat mengakibatkan perkecambahan benih sintetik terhambat atau bahkan mati (Himayani dan Muslihatin, 2017).

Pada Tabel 2 terdapat beberapa bahan tambahan yang dapat digunakan dalam campuran matrik benih sintetik yaitu medium basal, misal medium MS, Woody Plant, dan SH. Bahan tambahan ini sangat penting untuk pertumbuhan tunas dan akar dari embrio somatik yang dienkapsulasi (Raju et al., 2016). Sukrosa digunakan sebagai sumber energi dan menjaga tekanan osmotik yang akan mempengaruhi perkembangan embrio somatik (Roostika et al., 2012). Penggunaan IBA, BA, NAA, dan asam giberelin berguna untuk mendewasakan embrio somatik, sedangkan arang aktif berguna untuk mengatur $\mathrm{pH}$ serta meningkatkan atau mengatur hormon (George et al., 2008). Malt extract digunakan untuk memberikan sumber nitrogen organik yang mudah diserap embrio somatik yang berfungsi untuk pendewasaan embrio somatik (Rahmi et al., 2017). Penggunaan asam askorbat berfungsi untuk reduktase yang mengurangi radikal bebas (George et al., 2008).

Pada Tabel 2 penyimpanan benih sintetik pada kelas Magnoliopsida dapat dilakukan dengan suhu $4^{\circ} \mathrm{C}$ dan $25^{\circ} \mathrm{C}$. Suhu penyimpanan $4^{\circ} \mathrm{C}$ tidak memberikan hasil yang baik dalam durasi penyimpanan maupun kemampuan regenerasi menjadi plantlet, sedangkan penyimpanan benih sintetik pada suhu $25^{\circ} \mathrm{C}$ dapat memberikan durasi 45 hari dengan persentase regenerasi hingga $80 \%$. Prihatini dan Hadiati (2019), melaporkan bahwa benih sintetik tanaman nenas yang disimpan pada suhu $4^{\circ} \mathrm{C}$ beresiko mengurangi kemampuan benih sintetik untuk berkecambah, sedangkan menurut Roostika et al. (2012), melaporkan bahwa suhu penyimpanan tidak memberikan pengaruh nyata terhadap kemampuan berkecambah benih sintetik, namun berpengaruh terhadap daya tembus embrio somatik.

Kemampuan regenerasi dan durasi penyimpanan benih sintetik dapat dipengaruhi komposisi matrik benih sintetik ataupun suhu penyimpanan. Matrik benih sintetik kacapiring dapat ditambahkan dengan medium basal seperti MS dan sukrosa yang menjadi sumber nutrisi dan energi untuk menjaga viabilitas benih sintetik. Penambahan bahan lain yang dapat digunakan adalah durasi penyimpanan seperti asam absisat yang berperan dalam dormansi biji (Pranata, 2010). Suhu penyimpanan benih sintetik tanaman kacapiring yang dapat digunakan adalah $25^{\circ} \mathrm{C}$.

\section{Simpulan}

Pembuatan benih sintetik sangat potensial dikembangkan untuk perbanyakan tanaman kaca piring karena dalam waktu yang relatif singkat dapat menghasilkan bibit tanaman ang seragam dalam jumlah yang banyak dengan kualitas yang sama dengan induknya, benih dapat disimpan dalam waktu yang lama apabila belum akan digunakan untuk perkecambahan, serta dapat diaplikasikan langsung ke tanah. Salah satu bahan utama benih sintetik adalah embrio somatik. Untuk induksi embrio somatik pada tanaman $G$ jasminoides dapat dilakukan menggunakan hormon golongan sitokinin seperti TDZ atau menggunakan hormon golongan auksin seperti IAA, IBA, NAA, atau 2,4-D. Optimasi konsentrasi hormon ini perlu dilakukan untuk menghindari abnormalitas pada pertumbuhan embrio somatik dan tidak sinkronnya proses diferensiasi embrio somatik. Adapun untuk enkapsulasi embrio somatik pada tanaman $G$ jasminoides dapat menggunakan kombinasi natrium alginat $4 \%$, kalsium klorida atau kalsium nitrat $100 \mathrm{mM}$, durasi pencelupan 15 - 20 menit, bahan tambahan pada matrik berupa medium MS, sukrosa, maupun asam absisat, dan suhu penyimpanan benih sintetik terbaik adalah $25^{\circ} \mathrm{C}$.

\section{Daftar Pustaka}

Aboshama, H.M.S. (2011). Somatic embryogenesis proliferation, maturation and germination in Cajanus cajan. World Journal of Agricultural Sciences 7: 86-95. 
Anggraeni, T.D.A., Sulistyowati, E. \& Purwati, R.D. (2012). Pengaruh komposisi media dan sumber eksplan terhadap induksi kalus, perkecambahan, dan pertumbuhan tunas embrio somatik jarak pagar. Buletin Tanaman Tembakau, Serat dan Minyak Industri 4(2): 76-84.

Anitasari, S.D., Sari, D.N.R., Astarini, I.A. \& Defiani, M.R. (2018). Dasar Teknik Kultur Jaringan Tanaman. Deepublish. Yogyakarta.

Baskaran, P., Kumari, A. \& Staden, J. V. (2014). Embryogenesis and synthetic seed production in Mondiawhitei. Plant Cell, Tissue and Organ Culture 121(1): 205-214.

Bhojwani, S.S. (2012). Plant Tissue Culture: Applications and Limitations. Elsevier Science. New Delhi.

Buzzy, N.S., Herrera, R.R., Rosa, M., Avalos, M.G., Cortes, M., Pacheco, G.L.C., Canto, A., Pacheco, F.Q. \& Vargas, L. (2007). Advances in coffee tissue culture and its practical applications. In Vitro Cellular and Developmental Biology 43: 507-520.

Calandry, A.W., Muslihatin, W. \& Sutini. (2017). Produksi benih sintetik teh Camelliasinensis. Jurnal Sains dan Seni ITS 6(2): 45-47.

Capelle, S.C., Mok, D.W.S. \& Kirchner, S.C. (1983). Effects of thidiazuron on cytokinin autonomy and the metabolism of adenosine in callus tissues of Phaseoluslunatus L. Plant Physiology 73: 796-802.

Capuana, M. \& Debergh, P.C. (1997). Improvement of the maturation and germination of horse chesnut somatic embryos. Plant Cell, Tissue and Organ Culture 104: 125-130.

Cartes, R.P., Castellanos, B.H., Ríos, L.D., Saez, C.K., Spierccolli, H.S. \& Sanchez, O.M. (2009). Encapsulated somatic embryos and zygotic embryos for obtaining artificial seeds of rauli-beech (Nothofagusalpina (Poepp. \& Endl.) Oerst.). Chilean Journal of Agricultural Research 69(1): 112-118.

Chawla, H.S. (2002). Plant Biotechnology: A Practical Approach. Science Publishers. Pantnagar.

Chen, R. \& Baluska, F. (2013). Polar Auxin Transport, Signaling and Communication in Plants. Springer. Berlin.
Corredoira, E., Ballester, A. \& Vieitez, A.M. (2003). Proliferation, maturation and germination of Castaneasativa Mill. somatic embryos originated from leaf explants. Annals of Botany 92: 129-136.

Cruz, C.C., Arnao, G.M. \& Engelmann, F. (2013). Biotechnology and conservation of plant biodiversity. Resources 2(2): 73-95.

Deo, P.C., Tyagi, A.P., Taylor, M., Harding, R. \& Becker, D. (2010). Factors affecting somatic embryogenesis and transformation in modern plant breeding. The South Pacific Journal of Natural and Applied Sciences 28: 27-40.

Dewir, Y.H., Nurmansyah, Naidoo, Y. \& Teixeira da Silva, J.A. (2018). Thidiazuron-induced abnormalities in plant tissue cultures. Plant Cell Reports 37(11): 1451-1470.

Dhir, R., Shekhawat, G.S. \& Alam, A. (2014). Improved protocol for somatic embryogenesis and calcium alginate encapsulation in Anethumgraveolens L.: a medicinal herb. Applied Biochemistry and Biotechnology 173: 2267-2278.

Faisal, M. \& Alatar, A.A. (2019). Synthetic Seeds: Germplasm Regeneration, Preservation and Prospects. Springer Nature. Riyadh.

Farzinebrahimi, R., Taha, R.M., Rashid, K. \& Yaacob, J.S. (2014). The effect of various media and hormones via suspension culture on secondary metabolic activities of (cape jasmine) Gardeniajasminoides Ellis. The Scientific World Journal (407284): 1-7.

Gaber, M.K. \& Barakat, A.A. (2019). Micropropagation and somatic embryogenesis induction of Gardeniajasminoides plants. Alexandria Science Exchange Journal 40(1): 190-202.

Gabr, A.M.M., Arafa, N.M., El-Ashry, A.A.E. \& El-Bahr, M.K. (2017). Impact of zeatin and thidiazuron on phenols and flavonoids accumulation in callus cultures of gardenia (Gardeniajasminoides). Pakistan Journal of Biological Sciences 20(7): 328-335.

George, E.F., Hall, M.A. \& Klerk, G.D. (2008). Plant Propagation by Tissue Culture. 3 ed. Springer. Belanda.

Ghanbarali, S., Abdollahi, M.R., Zolnorian, H., Moosavi, S.S. \& Seguí-Simarro, J.M. (2016). Optimization of the conditions for production 
of synthetic seeds by encapsulation of axillary buds derived from minituber sprouts in potato (Solanumtuberosum). Plant Cell, Tissue and Organ Culture 126(3): 449-458.

Gray, D.J. (1992). Somatic embryogenesis and plant regeneration from immature zygotic embryos of muscadine grape (Vitisrotundifolia) cultivars. American Journal of Botany 79: 542-546.

Gray, D.J. (2005). Propagation From Non Meristematic Tissues. CRC Press. Boca Raton.

Greer, M.S. (2008). Effects of ammonium nitrate upon direct somatic embryogenesis and biolistic transformation of wheat [Thesis]. University of Lethbridge.

Guan, Y., Li, S.G., Fan, X.F. \& Su, Z.H. (2016). Application of somatic embryogenesis in woody plants. Frontiers in Plant Science 7: $1-12$.

Gupta, D.S. \& Ibaraki, Y. (2006). Plant Tissue Culture Engineering. Springer Science and Business Media. Dordrecht.

Haque, S.M. \& Ghosh, B. (2016). High-frequency somatic embryogenesis and artificial seeds for mass production of true-to-type plants in Ledebouriarevoluta: an important cardioprotective plant. Plant Cell, Tissue and Organ Culture 127(1): 71-83.

Hatzilazarou, S., Kostas, S. \& Economou, A.S. (2019). Plant regeneration of Neriumoleander L. from alginate-encapsulated shoot explants after short-term cold storage. Journal of Horticultural Science and Biotechnology 94(4): 441-447.

Himayani, C.E.S. \& Muslihatin, W. (2017). Produksi benih sintetik tanaman Moringa oleifera. Jurnal Sains dan Seni ITS 6(2): 5355.

Huetteman, C. \& Preece, J. (1993). Thidiazuron : A potent cytokinin for woody plant tissue culture. Plant Cell, Tissue and Organ Culture 33: 105-119.

Ibrahim, M.S.D., Hartati, R.R.S., Reflinur \& Sudarsono. (2018). Induksi embrio somatik sekunder kopi arabika dan deteksi keragaman somaklonal menggunakan marka SSRs. Jurnal Littri 24(1): 11-20.

Ibrahim, M.S.D., Hartati, R.R.S., Rubiyo, Purwito,
A. \& Sudarsono. (2015). The induction of primary and secondary somatic embryogenesis for arabica coffee propagation. Journal of Tropical Crop Science 2(3): 6-13.

Indrianto, A. \& Rusdianto. (2012). Induksi kalus embriogenik pada wortel (Daucuscarota L.) menggunakan 2,4-dichlorophenoxyacetic acid (2,4-D). Jurnal Bionature 13(2): 136140 .

ITIS. (2011). Rubiaceae of North America Update. https://www.itis.gov/servlet/SingleRpt/Single Rpt?search_topic=TSN\&search_value $=3516$ 3\#null.

Jain, S.M. \& Gupta, P.K. (2005). Protocol for Somatic Embryogenesis in Woody Plants. Springer Science and Business Media. Belanda.

Jainol, J.E. \& Gansau, J.A. (2017). Embryogenic callus induction from leaf tip explants and protocorm-like body formation and shoot proliferation of Dimorphorchislowii: Borneon endemic orchid. Agrivita 39(1): 110.

Jaiwal, P.K. \& Singh, J.R. (2003). Improvement Strategies of Leguminosae Biotechnology. Kluwer Academic Publisher. Inggris.

Jha, T.B. \& Ghosh, B. (2005). Plant Tissue Culture Basic and Applied. Universities Press. Hyderabad.

Kamińska, M., Gołębiewski, M., Tretyn, A. \& Trejgell, A. (2018). Efficient long-term conservation of Taraxacumpieninicum synthetic seeds in slow growth conditions. Plant Cell, Tissue and Organ Culture 132(3): 469-478.

Kobayashi, K.D. \& Kaufman, A.J. (2006). Common Gardenia. University of Hawaii/ Hawaii.

Kutschera, U. (1994). The current status of the acid-growth hypothesis. New Phytologist (126): 549-569.

Lestari, E.G. (2015). Peran thidiazuron dalam peningkatan kemampuan proliferasi tanaman secara invitro. Jurnal Penelitian dan Pengembangan Pertanian 32(2): 87-93.

Loschiavo, F., Pitto, L., Giuliano, G., Torti, G., Nuti-Ronchi, V., Marazziti, D., Vergara, R., Orselli, S. \& Terzi, M. (1989). DNA 
methylation of embryogenic carrot cell cultures and its variations as caused by mutation, differentiation, hormones and hypomethylating drugs. Theoretical and Applied Genetics 77(3): 325-331.

Lu, C. (1993). The use of thidiazuron in tissue culture. In Vitro Cellular \& Developmental Biology 29(2): 92-96.

Marquez-Martin, B., Sesmeroa, R., Quesadab, M.A., Pliego-Alfaroc, F. \& Sánchez-Romero, C. (2011). Water relations in culture media influence maturation of avocado somatic embryos. Journal of Plant Physiology 168: 2028-2034.

Mastuti, R. (2017). Dasar-dasar Kultur Jaringan Tumbuhan. Universitas Brawijaya Press. Malang.

Micheli, M. \& Standardi, A. (2016). From somatic embryo to synthetic seed in Citrus spp. through the encapsulation technology. In Vitro Embryogenesis in Higher Plants, Methods in Molecular Biology 1359: 405413.

Montoro, P., Carron, M.P., Granet, F., Lardet, L. \& Leclercq, J. (2012). Development of new varietal types based on rejuvenation by somatic embryogenesis and propagation by conventional budding or microcutting in Hevea brasiliensis. Acta Horticulturae 961: 553-576.

Murashige, T. (1977). Plant cell and organ cultures as horticultural practices. Symposium on Tissue Culture for Horticultural Purposes 78: 17-30.

Muslihatin, W., Jadid, N., Puspitasari, I.D. \& Safitri, C.E. (2017). Growth of vegetative explant Moringaoleifera on different composition of auxin and cytokinin and its synthetic seed germination. Proceeding of International Biology Conference 1854: 1-8.

Muslihatin, W., Jadid, N., Saputro, T.B., Purwani, K.I., Himayani, C.E.S. \& Calandry, A.W. (2018). Characteristic of synthetic seeds from two medicinal plants (Moringaoleifera and Camelliasinensis). Journal of Physics: Conference Series 1040(1): 1-6.

Niranjan, M.H. \& Sudarshana, M.S. (2005). In vitro response of encapsulated somatic embryos of Lagerstroemiaindica L. Indian Journal of Experimental Biology 43(6): 552554.
Nowak, K., Wójcikowska, B. \& Gaj, M.D. (2015). ERF022 impacts the induction of somatic embryogenesis in Arabidopsis through the ethylenerelated pathway. Planta 241: 967985.

Ouyang, Y., Chen, Y., Lü, J., Teixeira Da Silva, J.A., Zhang, X. \& Ma, G. (2016). Somatic embryogenesis and enhanced shoot organogenesis in Metabriggsiaovalifolia W. T. Wang. Scientific Reports 6(4): 1-9.

Paunescu, A. (2008). Histological investigation of the secondary somatic embryogenesis of Alyssumborzaeanum (Brassicaceae). Phytologia Balcanica 14: 111-117.

Prakash, A.V., Nair, D.S., Alex, S., Soni, K.B., Viji, M.M. \& Reghunath, B.R. (2018). Calcium alginate encapsulated synthetic seed production in Plumbagorosea L. for germplasm exchange and distribution. Physiology and Molecular Biology of Plants 24(5): 963-971.

Preeti, S., Pandey, S., Bhattacharya, A., Nagar, P.K. \& Ahuja, P.S. (2004). ABA associated biochemical changes during somatic embryo development in Camelliasinensis (L.) Kuntze. Plant Physiology 161: 1269-1276.

Prihatini, R. \& Hadiati, S. (2019). Teknik enkapsulasi sederhana untuk konservasi in vitro jangka menengah tanaman nenas (Ananascomosus). Jurnal Hortikultura 29(1): 1-8.

Purwanta, S., Sumantoro, P., Setyaningrum, H.D. \& Saparinto, C. (2015). Budidaya dan Bisnis Kayu Jati. Penebar Swadaya Grup. Jakarta.

Rahardja, P.C. \& Wiryanta, W. (2003). Aneka Cara Memperbanyak Tanaman. Agromedia Pustaka. Jakarta.

Rahmi, A.F., Purwito, A., Husni, A. \& Dinarti, D. (2017). Embriogenesis dan desikasi embrio somatik jeruk keprok batu 55 (Citrus reticulata Blanco.) untuk meningkatkan frekuensi perkecambahan. Jurnal Hortikultura Indonesia 8(2): 79-87.

Raju, C.S., Aslam, A. \& Shajahan, A. (2016). Germination and storability of calciumalginate coated somatic embryos of mango ginger (Curcumaamada Roxb.). Horticulture Environment and Biotechnology 57(1): 8896. 
Ramarosandratana, A. V \& Staden, J. (2004). Effects of auxins and 2,3,5-triiodobenzoic acid on somatic embryo initiation from Norway spruce zygotic embryos (Piceaabies). Plant Cell, Tissue and Organ Culture 79: 105-107.

Reddy, M.Y. \& Saritha, K. V (2012). Callus induction and somatic embryogenesis of Gardenialatifolia Ait. International Journal of Current Science 4: 83-89.

Rihan, H.Z., Kareem, F., El-Mahrouk, M.E. \& Fuller, M.P. (2017). Artificial seeds (Principle, aspects and applications). Agronomy 7(4): 10-14.

Roberts, J.A. (2012). Plant Growth Regulators. Springer Science \& Business Media. New York.

Roostika, I., Purnamaningsih, R., Supriati, Y., Mariska, I., Khumaida, N. \& Wattimena, G.A. (2012). Pembentukan benih sintetik tanaman nenas. Jurnal Hortikultura 22(4): $316-326$

Sharma, V. \& Manchanda, H. (2019). Biological and Chemical Research. Research Journal of Pharmaceutical, Biological and Chemical Sciences 35(22): 861-867.

Shimizu, K., Nagaike, N., Yobuya, T. \& Edachi, T. (1997). Plant regeneration from suspension culture of Iris gemanica. Plant Cell, Tissue and Organ Culture 50: 27-31.

Slater, A., Scott, N.W. \& Fowler, M.R. (2003). Plant Biotechnology. Oxford University Press. Inggris.

Standardi, A. \& Micheli, M. (2013). Encapsulation of invitro-derived explants: An innovative tool for nurseries. Methods in Molecular Biology 11013: 397-418.

Sumaryono \& Rizka, T. (2015). Pengaruh matriks kapsul terhadap perkecambahan benih sintetik teh (Cameliasinensis L.). Menara Perkebunan 83(2): 54-59.

Sunandar, A., Dorly \& Supena, E.D.J. (2017). Induction of somatic embryogenesis in sengon (Falcatariamoluccana) with thidiazuron and light treatments. HAYATI Journal of Biosciences 24(2): 105-108.

Taryono. (2016). Pengantar Bioteknologi Untuk Pemuliaan Tanaman. UGM Press. Yogyakarta.
Thomas, J.C. \& Katterman, F.R. (1986). Cytokinin activity induced by thidiazuron. Plant Physiology 81: 681-683.

Uswatunnisa, Sunaryo \& Sitawati. (2018). Pengaruh GA 3 terhadap pertumbuhan dan waktu muncul kuncup bunga kacapiring (Gardeniaaugusta Merr.). Jurnal Produksi Tanaman 6(10): 2406-2412.

Varis, S., Klimaszewska, K. \& Aronen, T. (2018). Somatic embryogenesis and plant regeneration from primordial shoot explants of Piceaabies (L.) H. Karst. somatic trees. Frontiers in Plant Science 871: 1-8.

Verma, S.K., Das, A.K., Cingoz, G.S., Uslu, E. \& Gurel, E. (2016). Influence of nutrient media on callus induction, somatic embryogenesis and plant regeneration in selected Turkish crocus species. Biotechnology Reports 10: 66-74.

Vesco, L.L.D. \& Gurerra, M.P. (2001). The effectiveness of nitrogen sources in feijoa somatic embryogenesis. Plant Cell and Organ Culture 64: 19-35.

Xiao, W., Li, S., Wang, S. \& Ho, C.T. (2017). Chemistry and bioactivity of Gardeniajasminoides. Journal of Food and Drug Analysis 25(1): 43-61.

Yelnititis. (2013). Induksi embrio somatik Shoreapinanga Scheff. pada kondisi fisik media berbeda. Jurnal Pemuliaan Tanaman Hutan 7(2): 73-84.

Zimmerman, J.L. (1993). Somatic embryogenesis: a model for early development in higher plants. The Plant Cell 5: 1411-1423 